\title{
Activity of enzymes of energy metabolism in single human preimplantation embryos
}

\author{
K. L. Martin ${ }^{1}$, K. Hardy $^{2}$, R. M. L. Winston ${ }^{2}$ and H. J. Leese ${ }^{1}$ \\ ${ }^{1}$ Department of Biology, University of York, Heslington, York YO1 5DD, UK; and ${ }^{2}$ Institute of \\ Obstetrics and Gynaecology, Royal Postgraduate Medical School, Hammersmith Hospital, \\ Du Cane Road, London W12 ONN, UK
}

\begin{abstract}
A method was developed to measure the activities of enzymes in extracts from single human preimplantation embryos. The method permits the analysis of two enzymes plus appropriate controls in an extract from a single embryo, and was used to investigate the control of energy metabolism during the development of human embryos from the two-cell to the blastocyst stage. Hexokinase (HK), 6-phosphofructokinase (PFK), pyruvate kinase (PK), fructose-1,6-diphosphate aldolase (ALD), glucose phosphate isomerase (GPI), lactate dehydrogenase $(\mathrm{LDH})$, glucose-6-phosphate dehydrogenase $(\mathrm{G} 6 \mathrm{PDH})$ and 2-oxoglutarate dehydrogenase $(\mathrm{ODH})$ were all detectable, whereas glycogen phosphorylase (GP) was not. The enzyme activities of ODH, PFK, LDH, PK, GPI and G6PDH, averaged over all stages of development from the two-cell to blastocyst stage (days 2-6 after insemination), were 3.5, $6.6,15,69,73$ and 87 times greater than HK, respectively. The activity of ALD was very similar to that of HK. The activities of ALD, GPI, PFK, PK and LDH showed no significant variation with stage of development, although the activity of GPI fell significantly from the four-eight cell to the eight-sixteen cell stage $(P<0.05)$. HK activity decreased from the two-eight cell to the eight-sixteen cell $(P<0.05)$, and increased significantly from the eight-sixteen cell to the blastocyst stage $(P<0.01)$. The overall relationship between hexokinase activity and stage approached significance $(P=0.059$, one-way analysis of variance). The activity of G6PDH decreased significantly with development $(P<0.001$, one way analysis of variance). The data suggest that hexokinase plays a key role in the control of glucose utilization in the early human embryo, although a role for PFK is not ruled out. The fact that GP could not be detected suggests that the breakdown of glycogen contributes very little to the energy metabolism of the human preimplantation embryo. The absolute and relative enzyme activities in the human embryo are comparable to those in adult tissues, although that of G6PDH is very high and that of GP is low. The activities of the enzymes are discussed in relation to the changes in pyruvate and glucose uptake and the production of lactate, during early human development.
\end{abstract}

\section{Introduction}

Preimplantation mammalian embryos generate ATP largely via the uptake and metabolism of exogenous nutrients present in oviduct and uterine fluids in vivo, and in culture media in vitro (Biggers and Stern, 1973; Wales, 1975; Leese, 1991). The early developmental stages are characterized by low metabolic activity and the oxidation of substrates such as pyruvate and lactate. Glucose may be toxic at this time (Chatot et al., 1989), although this effect depends on the media (Lawitts and Biggers, 1992). The main features of the later stages, especially the blastocyst, are an increase in metabolic activity and a switch to the consumption of glucose, some or all of which is converted

Revised manuscript received 24 March 1993. to lactate (Leese and Barton, 1984; Gardner and Leese, 1986, 1988; Hardy et al., 1989; Gott et al., 1990; Brison and Leese, 1991). The switch in energy substrate preference suggests a block to glucose utilization during the early developmental stages. This paper is concerned with the enzymatic basis of the control of energy metabolism in early human embryos.

Two experimental approaches are commonly used to investigate the control of metabolism. The first is the measurement of maximal enzyme activities in vitro; the second is the determination of metabolite concentrations and calculation of mass action ratios (Newsholme and Start, 1973). Both approaches have been used to elucidate the biochemical basis of the block to glucose utilization during early development in mouse embryos. Key enzymes of energy metabolism have been measured, including 6-phosphofructokinase (PFK) (Brinster, 1971) and hexokinase (HK) (Brinster, 1968a; 
Hooper and Leese, 1989). The activity of 6-phosphofructokinase is greater than that of hexokinase, and shows no significant variation with embryo development. By comparison, hexokinase increases from the eight-cell to the blastocyst stage, in parallel with the rise in glucose uptake at this time. However, the activity of $\mathrm{HK}$ is about four times greater than the consumption of glucose at each stage of development (Gardner and Leese, 1986; Hooper and Leese, 1989).

Barbehenn et al. (1974, 1978) used enzymatic cycling techniques to measure the concentrations of key metabolites in single mouse embryos. The embryos, at a variety of developmental stages, were cultured in substrate-free media for $60 \mathrm{~min}$, and glucose or glucose and pyruvate were then added. The effects of this treatment on metabolite concentrations suggested that the metabolic block to glucose utilization resided at the level of 6-phosphofructokinase, although roles for hexokinase and the transport of glucose into the embryo were not ruled out; this conclusion was also reached by Gardner and Leese (1988).

Nutrient uptake in the early human embryo differs both qualitatively and quantitatively from that in the mouse. Significant amounts of glucose are taken up by the human embryo during the early stages of development, and the subsequent fall in pyruvate and rise in glucose uptake is less dramatic. If the difference in volume of the embryos in the two species is taken into account, the uptake of glucose is similar, but pyruvate consumption is approximately four times greater in the human than in the mouse embryo (Hardy, 1992; K. Hardy, unpublished observation). Chi et al. (1988) measured the activity of 17 metabolic enzymes in human and mouse oocytes and found that the activities differed considerably between the two species. Data on the enzyme content of human preimplantation embryos were not presented.

We have measured the maximal activities of nine enzymes of energy metabolism in single spare human embryos at different stages of development. The choice of which enzymes to measure, although constrained by the availability of surplus human embryos, was made on the following basis. Glycogen phosphorylase (GP) and 6-phosphofructokinase were chosen since they are considered to provide a quantitative index of the maximum flux of glycolysis from glycogen (Newsholme et al., 1980; Newsholme and Crabtree, 1986). Hexokinase and 2-oxoglutarate dehydrogenase (ODH) are considered to indicate the maximum flux of glycolysis from glucose and the tricarboxylic acid cycle (TCA cycle), respectively (Newsholme et al., 1980; Newsholme and Crabtree, 1986). Pyruvate kinase (PK) is a further glycolytic enzyme which is considered potentially rate-limiting because it catalyses a nonequilibrium reaction. Glucose phosphate isomerase (GPI), fructose-1,6-diphosphate aldolase (ALD) and lactate dehydrogenase (LDH), although regarded as non-regulatory, provide examples of enzymes that may catalyse near-to equilibrium reactions in glycolysis. Moreover, GPI has been measured in human embryos by West et al. (1989). Finally, glucose-6-phosphate dehydrogenase (G6PDH), an Xchromosome linked enzyme, was included, which may indicate the potential activity of the pentose phosphate pathway which is responsible for generating NADPH and ribose moieties for biosynthetic processes.

\section{Materials and Methods}

\section{Embryo collection}

Ethical permission for the work was obtained from the UK Interim Licensing Authority (ILA), now the Human Fertilization and Embryology Authority (HFEA), and from the Ethics Committees of the collaborating institutions.

Donated, surplus human embryos were obtained from patients undergoing IVF treatment at the Royal Postgraduate Medical School, Hammersmith Hospital, London. The superovulation procedure involved pituitary-gonadal suppression and an LHRH agonist (Buserelin: Hoechst, Hounslow, Middlesex, UK), prior to and during superovulation with human menopausal gonadotrophin (hMG; Pergonal: Serono, Welwyn Garden City, Herts., UK) (Hillier et al., 1985; Rutherford et al., 1988). Ovulation was induced with 10000 iu hCG (Pregnyl: Organon, Cambridge, UK). Oocytes were retrieved $32-36 \mathrm{~h}$ later, and were preincubated for $4-8 \mathrm{~h}$ and inseminated (day 0), as described by Hillier et al. (1984). After 15-18 h the oocytes were checked for the presence of pronuclei to confirm fertilization (day 1).

Embryos were cultured in $1 \mathrm{ml}$ of either T6 medium (Quinn et al., 1982) or Earle's balanced salt solution (Gibco, Paisley, $\mathrm{UK}$ ), under a gas phase of $5 \% \mathrm{O}_{2}: 5 \% \mathrm{CO}_{2}: 90 \% \mathrm{~N}_{2}$. Both media were supplemented with $10 \%$ heat-inactivated maternal serum, and in the case of the Earle's, with $25 \mathrm{mmol}$ sodium bicarbonate $\mathrm{l}^{-1}, 0.47 \mathrm{mmol}$ pyruvate $\mathrm{l}^{-1}$ and antibiotics. On day $2(40-42 \mathrm{~h}$ after insemination) each embryo was examined, graded morphologically (Conaghan et al., 1993) and the best two or three selected for embryo transfer on day 2 or 3 .

After obtaining the patients' consent, any remaining cumulus cells were removed from the surplus embryos by gentle suction through a narrow bore pipette. The embryos were then cultured in the original $1 \mathrm{ml}$ of medium or in $20 \mu \mathrm{l}$ drops of the same medium under paraffin oil.

\section{Enzyme extraction}

Human embryos were removed from culture at a variety of developmental stages, scored and placed singly in $2.5 \mu$ of an extraction medium in a $5 \mu \mathrm{l}$ microcapillary (Drummond Scientific, UK), the ends of which were sealed with parafilm. The medium served to extract, solubilize and preserve the enzymes; its composition was based on that used by Chi et al. (1988) and contained $50 \mathrm{mmol} \mathrm{K}_{2} \mathrm{HPO}_{4} \mathrm{l}^{-1}, 25 \%$ glycerol, $0.5 \mathrm{mmol}$ EDTA $~^{-1}, 5 \mathrm{mmol} \beta$-mercaptoethanol $\mathrm{l}^{-1}$ (BDH, Merck Ltd, Poole), $2 \mathrm{mg} \mathrm{BSA} \mathrm{ml}^{-1}$ (ICN Biomedicals, High Wycombe) and $0.5 \%$ Triton $\mathrm{X}-100$, at $\mathrm{pH} 7.5$. Samples were frozen immediately and stored at $-70^{\circ} \mathrm{C}$ before analysis. The zona pellucida remained intact. The presence of the zona has been shown not to limit enzyme activity measured in vitro (Brinster, 1965, 1966).

\section{Enzyme assay technique}

To measure enzyme activity in single human embryos it was necessary to miniaturize the conventional methods of analysis in which NADH or NADPH are generated or consumed in coupled reactions. The method developed was based on the 
ultramicrofluorescence techniques of Mroz and Lechene (1980), Leese et al. (1984) and Leese and Barton (1984).

Enzyme assays were carried out in a total volume of $1 \mu \mathrm{l}$ or $1.5 \mu \mathrm{l}$, in sealed $5 \mu \mathrm{l}$ microcapillaries, by adding $0.5 \mu \mathrm{l}$ or $1.0 \mu \mathrm{l}$ of thawed embryo extract to $0.5 \mu$ l of reaction mixture. Enzyme activity, measured as the rate of appearance or disappearance of $\mathrm{NADH}$ or the appearance of NADPH, was monitored using a Fluovert inverted microscope with MPV compact 2 photometer and photomultiplier attachments (Leica, Milton Keynes). There was a linear relationship between $\mathrm{NAD}(\mathrm{P}) \mathrm{H}$ concentration and arbitrary units of fluorescence in the range $0-2 \mathrm{mmol} \mathrm{l}^{-1}$.

Changes in fluorescence owing to nonspecific oxidation of $\mathrm{NADH}$, or reduction of $\mathrm{NAD}(\mathrm{P})^{+}$were accounted for by including controls for each enzyme assay, in which the substrate was omitted. For enzyme reactions in which $\mathrm{NAD}^{+}$or $\mathrm{NADP}^{+}$ were reduced, there was no significant increase in fluorescence in the absence of substrate. For reactions involving NADH oxidation, a small fall in fluorescence was usually observed in the absence of substrate, and was therefore subtracted from the rate for each enzyme in the presence of substrate. Reaction rates were recorded for a minimum of $1 \mathrm{~h}$ and were linear during the period over which measurements were made.

The composition of the enzyme reaction mixtures are given below:

Hexokinase (EC 2.7.1.1) (Hooper and Leese, 1989): $100 \mathrm{mmol}$ triethanolamine $\mathrm{l}^{-1}, 5 \mathrm{mmol} \mathrm{MgCl}_{2} \mathrm{l}^{-1}, 5 \mathrm{mmol} \mathrm{ATP} \mathrm{l}^{-1}$, $1.5 \mathrm{mmol} \mathrm{NADP}^{+} \mathrm{I}^{-1}, 1 \mathrm{mmol}$ glucose $1^{-1}(\mathrm{BDH}), 5 \mathrm{U}$ glucose-6-phosphate dehydrogenase $\mathrm{ml}^{-1}$ (EC 1.1.1.49), $\mathrm{pH}$ 7.6.

6-Phosphofructokinase (EC 2.7.1.11) (modified from Brinster, 1971): $\quad 100 \mathrm{mmol} \mathrm{Tris}^{-} \mathrm{HCl}^{-1}$ (BDH), $100 \mathrm{mmol} \mathrm{KCl}^{-1}$ (BDH), $5 \mathrm{mmol} \mathrm{MgCl}_{2} 1^{-1}, 1 \mathrm{mmol}$ EDTA $1^{-1}, 10 \mathrm{mmol}$ fructose-6-phosphate $\mathrm{I}^{-1}, 10 \mathrm{mmol}$ ATP $\mathrm{l}^{-1}, 5 \mathrm{mmol}$ NADH $\mathrm{l}^{-1}, 1 \mathrm{mmol}$ dithiothreitol $\mathrm{l}^{-1}, 10 \mu \mathrm{g}$ aldolase $\mathrm{ml}^{-1}$ (EC 4.1.2.13), $10 \mu \mathrm{g}$ triosephosphate isomerase $\mathrm{ml}^{-1}$ (EC 5.3.1.1), $170 \mathrm{U}$ glycerol-3-phosphate dehydrogenase $\mathrm{mg}^{-1}$ (EC 1.1.1.8), $\mathrm{pH} 8.0$.

Pyruvate kinase (EC 2.7.1.40) (Chi et al., 1988): $50 \mathrm{mmol}$ imidazole- $\mathrm{HCl}^{-1}$ (Boehringer Mannheim, Lewes), $0.1 \mathrm{~mol} \mathrm{KCl}$ $\mathrm{l}^{-1}, 3 \mathrm{mmol} \mathrm{MgCl}_{2} \mathrm{l}^{-1}, 1 \mathrm{mmol}$ ADP $\mathrm{l}^{-1}, 10 \mathrm{mmol} \mathrm{5}$-AMP $1^{-1}, 1 \mathrm{mmol}$ phosphoenolpyruvate $\mathrm{I}^{-1}, 500 \mu \mathrm{mol} \mathrm{NADH} \mathrm{l}^{-1}$, $2 \mu \mathrm{g}$ lactate dehydrogenase $\mathrm{ml}^{-1}$ (EC 1.1.1.27), $\mathrm{pH}$ 7.0.

Fructose-1,6-diphosphate aldolase (EC 4.1.2.13) (Bergmeyer, 1983): $94 \mathrm{mmol}$ triethanolamine $\mathrm{I}^{-1}, 0.2 \mathrm{mmol} \mathrm{NADH} \mathrm{l}^{-1}$, $1.1 \mathrm{mmol}$ fructose-1,6-diphosphate $\mathrm{l}^{-1}, 170 \mathrm{U}$ glycerol-3-phosphate dehydrogenase $\mathrm{mg}^{-1}$ (EC 1.1.1.8), 5000 U triosephosphate isomerase $\mathrm{mg}^{-1}$ (EC 5.3.1.1), $\mathrm{pH}$ 7.6.

Glucose phosphate isomerase (EC 5.3.1.9) (Bergmeyer, 1983): $85 \mathrm{mmol}$ triethanolamine $\mathrm{I}^{-1}, 1.4 \mathrm{mmol}$ fructose-6-phosphate $\mathrm{I}^{-1}, 6.8 \mathrm{mmol} \mathrm{MgCl}_{2} \mathrm{I}^{-1}, 0.39 \mathrm{mmol} \mathrm{NADP}^{+} 1^{-1}, 140 \mathrm{U}$ glucose-6-phosphate dehydrogenase $\mathrm{mg}^{-1}$ (EC 1.1.1.49), pH 7.6.

Lactate dehydrogenase (EC 1.1.1.27) (modified from Brinster, 1965): $70 \mathrm{mmol} \mathrm{KH_{2 }} \mathrm{PO}_{4} \mathrm{l}^{-1}, 0.4 \mathrm{mmol} \mathrm{K} \mathrm{HPO}_{4} \mathrm{l}^{-1}, 4 \mathrm{mmol}$ NADH $l^{-1}, 8 \mathrm{mmol}$ pyruvate $1^{-1}, 7.8 \mathrm{mmol} \mathrm{NaHCO}_{3} \mathrm{l}^{-1}$ (BDH), pH 7.6.
Glucose-6-phosphate dehydrogenase (EC 1.1.1.49): $86 \mathrm{mmol}$ triethanolamine $1^{-1}, 1 \mathrm{mmol}$ glucose-6-phosphate $\mathrm{I}^{-1}$, $0.5 \mathrm{mmol} \mathrm{NADP}^{+} \mathrm{1}^{-1}, 7 \mathrm{mmol} \mathrm{MgCl} \mathrm{1}^{-1}, \mathrm{pH}$ 7.6.

2-Oxoglutarate dehydrogenase (EC 1.2.4.2) (Cooney et al., 1981): $250 \mathrm{mmol}$ mannitol $\mathrm{I}^{-1}(\mathrm{BDH}), 10 \mathrm{mmol} \mathrm{KPO}_{4} \mathrm{I}^{-1}$, $100 \mathrm{mmol} \mathrm{KCl} \mathrm{l}^{-1}, 5 \mathrm{mmol} \mathrm{MgCl}_{2} \mathrm{l}^{-1}, 1 \mathrm{mmol}$ dithiothreitol $1^{-1}, 0.05 \%$ Triton X-100, $2 \mathrm{mmol} \mathrm{NAD}^{+} 1^{-1}, 0.6 \mathrm{mmol}$ coenzyme $\mathrm{Al}^{-1}, 10 \mathrm{mmol} 2$-oxoglutarate ${ }^{-1}$, $\mathrm{pH} 7.4$.

Glycogen phosphorylase (EC 2.4.1.1) (Chi et al., 1988): $50 \mathrm{mmol}$ imidazole- $\mathrm{HCl}^{-1}, 0.4 \%$ glycogen, $1 \mu \mathrm{mol}$ glucose-1,6-diphosphate $1^{-1}, 1 \mathrm{mmol} \mathrm{NADP}^{+} 1^{-1}, 3 \mu \mathrm{g}$ phosphoglucomutase $\mathrm{ml}^{-1}$ (EC 5.4.2.2), $2 \mu \mathrm{l}$ glucose-6-phosphate dehydrogenase $\mathrm{ml}^{-1}$ (EC 1.1.1.49), $1 \mathrm{mmol}$ AMP l-1,0.5 mmol $\mathrm{MgCl}_{2} \mathrm{l}^{-1}$, $20 \mathrm{mmol} \mathrm{K}_{2} \mathrm{HPO}_{4} \mathrm{l}^{-1}$, pH 7.0.

Auxillary enzymes and nicotinamide nucleotides were obtained from Boehringer Mannheim (Lewes); all other chemicals were from Sigma Chemical Company (Poole) or Fisons (Loughborough) unless otherwise stated.

\section{Embryo quality}

All the embryos were normally fertilized as confirmed by the presence of two pronuclei on day 1 . Arrested embryos were eliminated from the study. On days 2-6 after insemination, the embryos were at the following stages: two-four cell (day 2); four-eight cell (day 3); eight-cell-morula (day 4); morulablastocyst (day 5); morula-late blastocyst (day 6). The following criteria were used to classify the embryos into grades 1-5: grade 1 embryos had the expected number of blastomeres for the time of transfer, which were uniform and intact, with no extracellular fragmentation; grade 2 embryos exhibited one of the following: slow development, asymmetrical blastomeres, or fragmentation; grade 3 embryos had one degenerate blastomere, with the remaining cells intact; grade 4 embryos had at least one blastomere intact; and grade 5 embryos had no intact cells (Conaghan et al., 1993). Embryos were randomly assigned to each enzyme assay. The embryos used in this study were classified as follows: grade $1(7 \%)$, grade $1.5(14 \%)$, grade 2 $(47 \%)$, grade $2.5(19 \%)$, grade $3(8 \%)$, grade $3.5(4 \%)$, grade $4-4.5(2 \%$ ). For each enzyme assayed, $77-87.5 \%$ (mean $87 \%$ ) of the embryos were of grade 2.5 or above. The small numbers of embryos available precluded any further analysis of enzyme activity versus grade.

\section{Expression of results}

Enzyme activities were expressed as nmoles substrate consumed per embryo $\mathrm{h}^{-1}$ at $20^{\circ} \mathrm{C}$. The statistical significance of the results was analysed using Student's $t$ test and one-way analysis of variance. Student's $t$ test was used to analyse for differences between mean enzyme activities on separate days of development. One-way analysis of variance was used to test for an overall relationship between enzyme activity and developmental stage.

Previously published values for enzyme activities in human oocytes at $25^{\circ} \mathrm{C}, 35^{\circ} \mathrm{C}$ or $37^{\circ} \mathrm{C}$ were compared with those 
Table 1. Maximal enzyme activities in single human preimplantation embryos averaged over all stages of development from the two-cell to blastocyst stage

(days 2-6 after insemination)

\begin{tabular}{llc}
\hline Enzyme & $\begin{array}{c}\text { Mean maximal activity } \\
\text { (nmol substrate consumed } \\
\text { per embryo } \mathrm{h}^{-1} \pm \mathrm{SEM} \text { ) }\end{array}$ & $\begin{array}{c}\text { Number } \\
\text { of } \\
\text { embryos }\end{array}$ \\
\hline Hexokinase & $0.0464 \pm 0.0059$ & 36 \\
6-Phosphofructokinase & $0.313 \pm 0.061$ & 21 \\
Pyruvate kinase & $3.22 \pm 0.36$ & 28 \\
Fructose-1,6-diphosphate aldolase & $0.0425 \pm 0.0074$ & 18 \\
Glucose phosphate isomerase & $3.38 \pm 0.40$ & 18 \\
Lactate dehydrogenase & $0.698 \pm 0.079$ & 29 \\
Glucose-6-phosphate dehydrogenase & $4.04 \pm 0.31$ & 27 \\
2-Oxoglutarate dehydrogenase & $0.162 \pm 0.059$ & 10 \\
Glycogen phosphorylase & not detectable & 8 \\
\hline
\end{tabular}

obtained in the present study for human embryos at $20^{\circ} \mathrm{C}$, by assuming a $Q_{10}$ of 2 ; i.e. that for every rise in $10^{\circ} \mathrm{C}$, enzyme activity was doubled.

The dry mass of a human embryo was estimated as $181 \mathrm{ng}$ on the basis of values obtained for single mouse embryos (Turner et al., 1992) and by assuming that the human embryo has a volume five times greater than that of the mouse. This was calculated from the diameter of mouse and human embryos, at the eight-cell to morula stage, which were $75.3 \pm 3.4 \mu \mathrm{m}$ $(n=10)$ and $129.5 \pm 7.0 \mu \mathrm{m}(n=5)$, respectively (K. Hardy and K. L. Martin, unpublished observations). The estimated value agrees well with that of $175 \mathrm{ng}$ obtained for morphologically normal oocytes by Chi et al. (1988).

\section{Results}

\section{Comparison of enzyme activities}

All of the enzymes assayed were detected except glycogen phosphorylase. The maximum activity of each enzyme averaged over all stages of development from the two-cell to the blastocyst stage (day 2 to day 6 after insemination) is shown (Table 1; Fig. 1).

Of the eight enzymes detected, hexokinase and fructose1,6-diphosphate aldolase had the lowest activities. Pyruvate kinase, glucose phosphate isomerase and glucose-6-phosphate dehydrogenase had the highest maximum activities with values 69,73 and 87 times greater than those of hexokinase, respectively. Enzymes with an intermediate range of activity were 2-oxoglutarate dehydrogenase, 6-phosphofructokinase and lactate dehydrogenase, the activities of which were $3.5,6.6$ and 15 times greater than hexokinase, respectively.

The enzyme activities, averaged over all stages of development, are compared with those measured by others on human oocytes (Fig. 2). Data for GPI measured in five human embryos by West et al. (1989) are also included. The average enzyme activities measured in single human embryos and those reported for human oocytes are of the same order of magnitude.

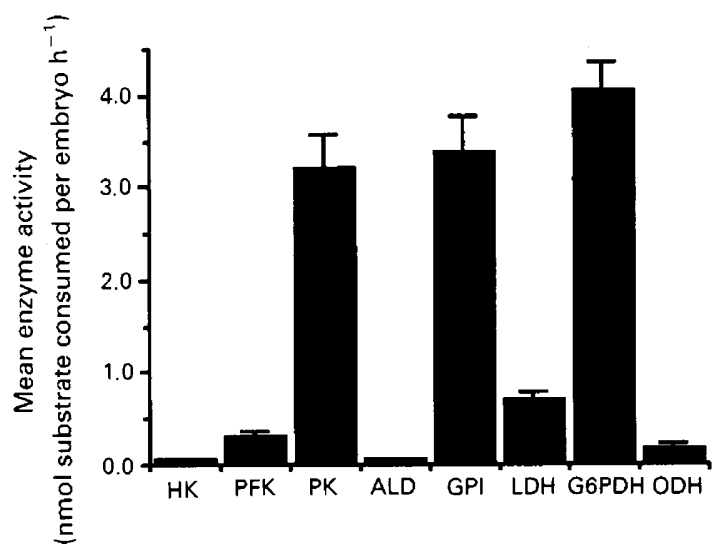

Fig. 1. Maximum enzyme activities in single human preimplantation embryos averaged over all stages of development from the two-cell to blastocyst stage (day 2 to day 6 after insemination). Values are nmol substrate consumed per embryo $\mathrm{h}^{-1} \pm \mathrm{SEM}$. The number of determinations for each enzyme is shown in Table I. Glycogen phosphorylase was not detectable. HK: hexokinase; PFK: 6-phosphofructokinase; PK: pyruvate kinase; ALD: fructose-1,6-diphosphate aldolase; GPI: glucose phosphate isomerase; $\mathrm{LDH}$ : lactate dehydrogenase; G6PDH: glucose6-phosphate dehydrogenase; $\mathrm{ODH}$ : 2-oxoglutarate dehydrogenase.

\section{Variation of enzyme activity with stage of development}

No significant variation with stage of development was seen for the enzymes 6-phosphofructokinase, pyruvate kinase, fructose-1,6-diphosphate aldolase, glucose phosphate isomerase and lactate dehydrogenase (Figs $3 b, c ; 4 a-c$ ), although the activity of GPI decreased from the four-eight cell to the eight-sixteen cell stage $(P<0.05)$. The maximum activity of hexokinase decreased from the two-eight cell to the eightsixteen cell stage $(P<0.05)$, and increased significantly from the eight-sixteen cell to the blastocyst stage of development $(P<0.01$; Fig. 3a). The overall relationship between hexokinase activity and stage approached significance $(P=0.059$, oneway analysis of variance). Glucose-6-phosphate dehydrogenase activity decreased significantly with stage of development $(P<0.001$, one-way analysis of variance; Fig. 5$)$. 


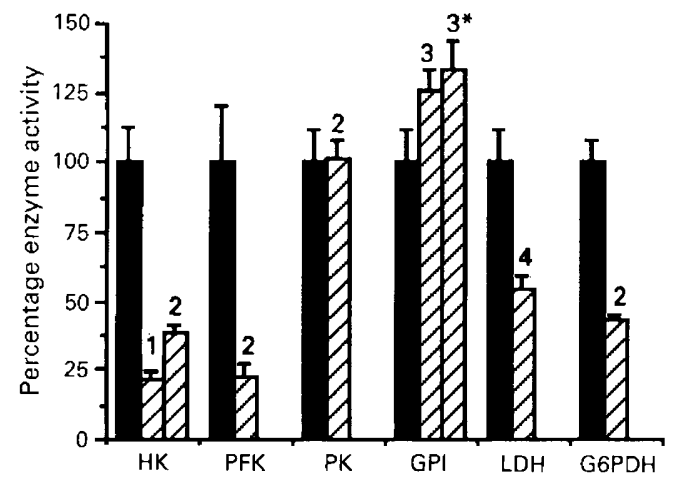

Fig. 2. Maximum activities of enzymes in single human preimplantation embryos averaged over all stages of development from the two-cell to blastocyst stage (day 2 to day 6 after insemination) ( $\square$ ), compared with previously published values for human oocytes and a mean value for GPI in five preimplantation embryos ${ }^{*}(\square)$. Enzyme activities are expressed as a percentage of the values obtained for human preimplantation embryos, in Table 1 and Fig. 1. HK: hexokinase; PFK: 6-phosphofructokinase; PK: pyruvate kinase; GPI: glucose phosphate isomerase; LDH: lactate dehydrogenase; G6PDH: glucose6-phosphate dehydrogenase. ${ }^{1}$ Tsutsumi et al. (1990); ${ }^{2} \mathrm{Chi}$ et al. (1988); ${ }^{3}$ West et al. (1989); ${ }^{4}$ Brinster (1968b).

\section{Discussion}

This is the first report of the developmental profile of enzymes concerned with energy metabolism in human preimplantation embryos. The method used permits the analysis of two enzymes, with appropriate controls, on an extract from a single embryo. It has the further advantage of enabling enzyme activity to be measured directly, without the use of enzymatic cycling techniques (Lowry and Passoneau, 1972), which are time-consuming and technically very demanding.

The absolute enzyme activities, expressed in terms of cell dry mass, compared well with those in adult mammalian tissues; heart, liver, kidney, lung, fat, brain and skeletal muscle (Lowry and Passoneau, 1964; Shonk and Boxer, 1964; Shonk et al., 1964; Crabtree and Newsholme, 1972; Budohoski et al., 1982; Blomstrand et al., 1983, 1986; Lowry et al., 1983; Board et al., 1990). This was especially the case for hexokinase, 6-phosphofructokinase, pyruvate kinase, fructose-1,6-diphosphate aldolase, glucose phosphate isomerase, lactate dehydrogenase and 2 oxoglutarate dehydrogenase. In contrast, the activity of glucose6-phosphate dehydrogenase in the embryos was extremely high, and that of glycogen phosphorylase low. When the enzyme activities for human embryos were expressed relative to hexokinase, the pattern for PFK, PK, ALD, GPI, LDH and ODH was similar to that found in the adult tissues listed above. The exceptions were again, $\mathrm{G} 6 \mathrm{PDH}$, the relative activity of which was very high and GP, which was low.

Potential exogenous and endogenous energy sources available to the human preimplantation embryo include glucose, pyruvate, lactate, glycogen, amino acids and lipids (Leese, 1991). The uptake of exogenous nutrients, glucose and pyruvate, and the formation of lactate, have been measured in single human embryos cultured in vitro (Hardy et al., 1989; Gott et al., 1990). During the early stages of development, pyruvate is consumed preferentially, before a significant increase in glucose uptake
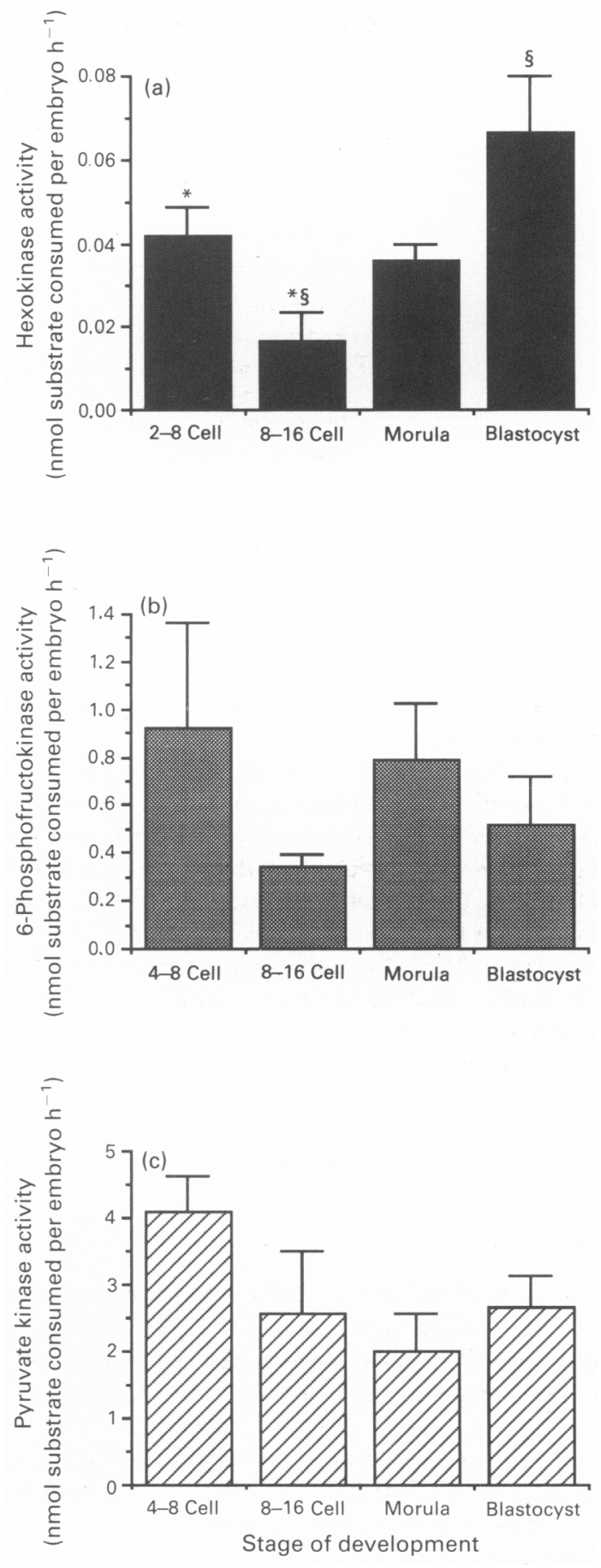

Fig. 3. Variation in enzyme activity with embryo development of: (a) hexokinase, (b) 6-phosphofructokinase and (c) pyruvate kinase. Enzyme activities were measured in extracts from single human preimplantation embryos. Values are means of an average of seven determinations for each stage of development (range 3-15), for total numbers assayed for each enzyme see Table 1 , and are expressed as nmol substrate consumed per embryo $\mathrm{h}^{-1} \pm$ SEM. The activity of hexokinase decreased from the four-eight cell to the eight-sixteen cell stage $(P<0.05)^{*}$, before increasing significantly from the eightsixteen cell to the blastocyst stage $(P<0.01) \S$, the variation of activity with development approached significance $(P=0.059$, one-way analysis of variance). 

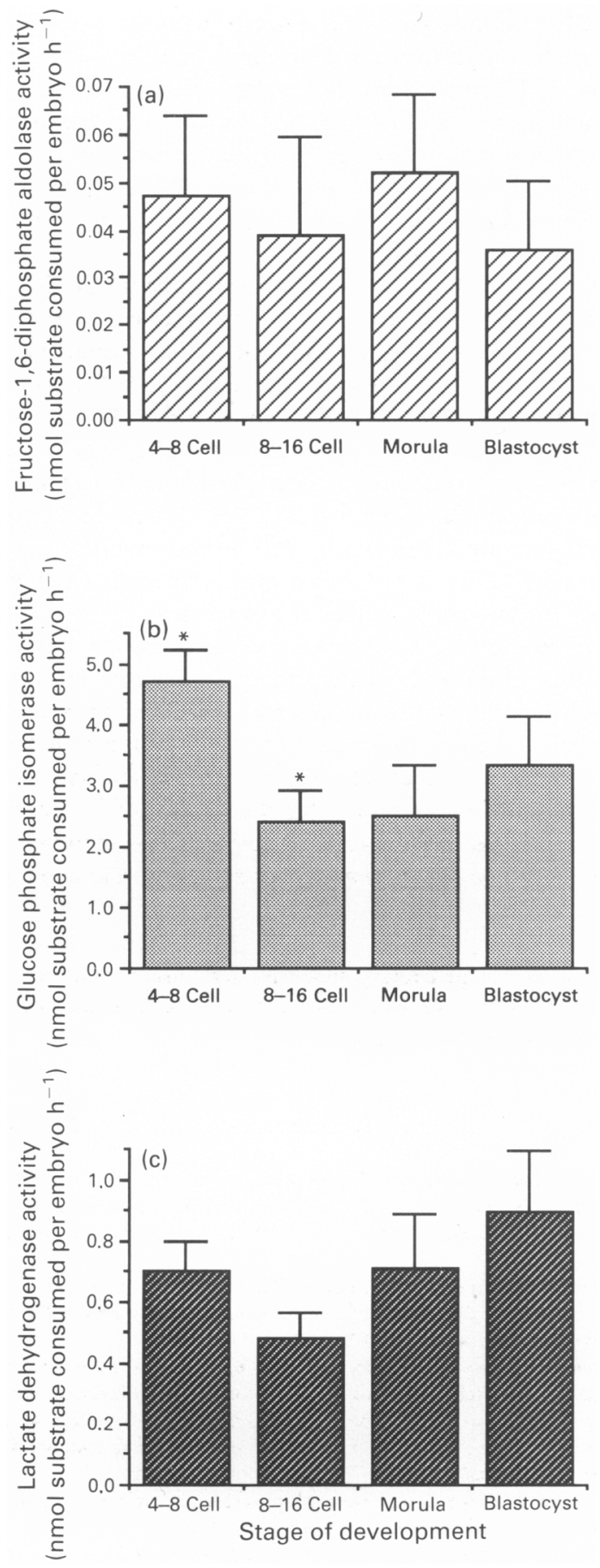

Fig. 4. Variation in enzyme activity with embryo development of (a) fructose-1,6-diphosphate aldolase, (b) glucose phosphate isomerase and (c) lactate dehydrogenase. Enzyme activities were measured in extracts from single human preimplantation embryos. Vaiues are means of an average of six determinations for each stage of development (range 3-9), for total numbers assayed for each enzyme see Table 1; and are expressed as nmol substrate consumed per embryo $\mathrm{h}^{-1} \pm \mathrm{SEM}$. No significant variation in activity with development was seen for the three enzymes, although the activity of glucose phosphate isomerase fell significantly from the four-eight cell to the eight-sixteen cell stage $(P<0.05)^{*}$.

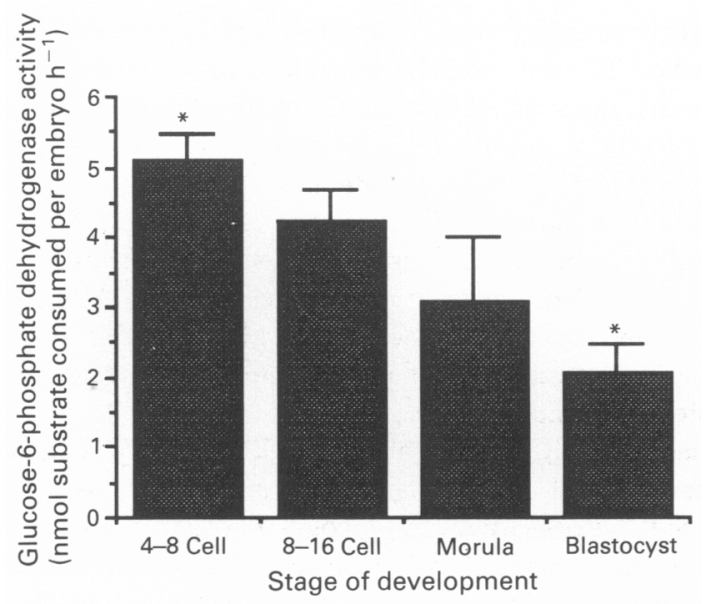

Fig. 5. Variation in activity of glucose-6-phosphate dehydrogenase with development. Enzyme activities were measured in extracts from single human preimplantation embryos. Values are means of six (range 3-8) determinations for each stage of development and are expressed as nmol substrate consumed per embryo $h^{-1} \pm$ SEM. G6PDH activity fell significantly with development $\left({ }^{*} P<0.001\right.$, one-way analysis of variance).

occurs between the morula and blastocyst stage, on days 3.5-5.5 after insemination.

The results reported here suggest that hexokinase may be important in regulating the metabolism of glucose in the human preimplantation embryo. Activities of the other two potentially rate-limiting enzymes in the glycolytic pathway, 6-phosphofructokinase and pyruvate kinase, averaged over all stages of development, were 6.6 and 70 times greater than hexokinase, respectively. In addition, the significant rise in hexokinase from the eight-sixteen cell to blastocyst stage (Fig. 3a) parallels the increase in glucose uptake (Hardy et al., 1989), although the activity of hexokinase is greater than the uptake of glucose at each stage of development, by a factor of $2-6$. The corresponding values for PFK and PK are 13-39 and 134-403, respectively, depending on which developmental stage is taken for comparison. However, a regulatory role for 6-phosphofructokinase is still likely, as is the case in the mouse embryo (Barbehenn et al., 1974, 1978), as the allosteric properties of this enzyme are not exhibited at the assay $\mathrm{pH}$ of 8.0.

The average and relative enzyme activities in human preimplantation embryos reported here compare well with those in human oocytes. This is especially the case for glucose phosphate isomerase (West et al., 1989) and pyruvate kinase (Chi et al., 1988). Hexokinase and 6-phosphofructokinase activities are 4.5 times greater in embryos than in oocytes, suggesting that of the glycolytic enzymes, they may become most important in the regulation of glucose metabolism after fertilization.

Total lactate production steadily increases with development in the human embryo, from $43.6 \mathrm{pmol}$ per embryo $\mathrm{h}^{-1}$ on day 2.5 after insemination to $95.4 \mathrm{pmol}$ per embryo $\mathrm{h}^{-1}$ on day 5.5 (Gott et al., 1990). Wales et al. (1987) reported a maximum value of $36.6 \mathrm{pmol}$ per embryo $\mathrm{h}^{-1}$ for lactate production from glucose, by the human blastocyst. The activity of LDH is 6-7 times greater than the total rate of lactate production, and 8-28 times greater than the potential contribution to lactate formation from the aerobic glycolysis of exogenous glucose (Wales et al., 1987; Gott et al., 1990). The activity of LDH in mouse preimplantation embryos is 
similarly far greater than the amount required to account for lactate production (Brinster, 1965; Epstein et al., 1969).

The activities of ALD and GPI in the human embryo are similar to those in the mouse (Epstein et al., 1969; West et al., 1986, 1989), if the fivefold difference in volume is taken into consideration. However, the activities of G6PDH, HK and PFK are higher in human than in mouse embryos (Brinster, 1966, 1968a, 1971; Epstein et al., 1969; Leese, 1987; Hooper and Leese, 1989) and cannot be accounted for in this way. The reverse is true for $\mathrm{LDH}$ which is $9-86$ times greater in mice (Brinster, 1965; Epstein et al., 1969).

It has been suggested that the breakdown of glycogen may contribute to the production of lactate in the human embryo (Gott et al., 1990). However, glycogen phosphorylase could not be detected, indicating that glucose is the main carbohydrate substrate for lactate production. The activity of GP in human oocytes is also extremely low, 0.095 pmol per oocyte $\mathrm{h}^{-1}$ (Chi et al., 1988). A comparison of the activities of enzymes involved in both glycogen synthesis and degradation indicate that GP is the rate-limiting enzyme of glycogen breakdown, and that net synthesis is favoured in both human and mouse oocytes (Chi et al., 1988), and in mouse preimplantation embryos (Hsieh et al., 1979). The fact that GP cannot be detected suggests that this may also apply to the human embryo, although further investigations are required.

The activity of glucose-6-phosphate dehydrogenase reported here fell significantly with development. G6PDH catalyses a reaction considered to be far from equilibrium and is the ratelimiting step of the pentose phosphate pathway in liver and adipose tissue (Newsholme and Leech, 1981). The activity in the human embryo suggests that the pathway has a potentially high activity, which decreases with time after fertilization. The activities of this enzyme are far greater than those required to support the pentose phosphate pathway, which has been shown in the rabbit and mouse embryo to represent less than $15 \%$ of glucose consumed (Fridhandler, 1961; O'Fallon and Wright, 1986). Even if all the exogenous glucose consumed by the human embryo was converted to glucose-6-phosphate, and subsequently metabolized by this pathway, the activity of G6PDH would still be greater, by a factor of 168-505.

Enzymes detected in the embryo up to the four-eight cell stage will be proteins synthesized from the mRNA inherited from the oocyte, as the embryonic genome is not activated until this time (Braude et al., 1988; Tesarik, 1988). The fall in G6PDH activity with development, which also occurs in the mouse embryo (Brinster, 1966; Leese, 1987), probably reflects the net degradation of enzyme coded for by the oocyte mRNA. The high activity of G6PDH in the human preimplantation embryo may therefore be due to the previous requirements of the oocyte; indeed, the activity measured in human oocytes is also high (Chi et al., 1988), although it is only half of that found in the embryo. However, the questionable quality of the unfertilized oocytes used by Chi et al. (1988), which had been incubated with spermatozoa for 3-4 days, may account for this difference.

The oxidative metabolism of pyruvate represents a large potential source of energy for the human embryo. 2-Oxoglutarate dehydrogenase is a multienzyme complex and one of the potentially rate-limiting enzymes of the TCA cycle, together with citrate synthase, isocitrate dehydrogenase and succinate dehydrogenase (Newsholme and Leech, 1981). Barbehenn et al.
$(1974,1978)$ suggested that an enzyme between 2-oxoglutarate and malate, might play a role in regulating the metabolism of glucose in the mouse preimplantation embryo. If such a step was rate-limiting, it could account for the high concentration of citrate found in the embryo (Barbehenn et al., 1978). Citrate inhibits 6-phosphofructokinase allosterically, and so may contribute to the block to glucose utilization in the early preimplantation stages.

The activity of ODH has been shown to equal the TCA cycle flux in muscles (Newsholme et al., 1980), rat heart (Randle et al., 1970; Cooney et al., 1981), and the hearts and mammary glands of ruminants and non-ruminants (Read et al., 1977). However, in rat lymphocytes, $\mathrm{ODH}$ activity was found to be greater than the TCA flux (Ardawi and Newsholme, 1982). The activity of $\mathrm{ODH}$ in the human embryo is comparable to the values found in adult tissues (Blomstrand et al., 1983, 1986). Assuming that all the pyruvate consumed by the human embryo enters the TCA cycle, ODH is $4-6$ times greater than that required to account for the oxidative flux of this nutrient.

In conclusion we have presented novel information on the phenotype of the early human embryo at the biochemical level. This information is essential to our understanding of the regulation of metabolic pathways and their integration with development, and is a prerequisite for the genetic analysis of these phenomena. Moreover, defining the control of metabolism in human embryos could enable improvements in embryo culture techniques to be made on a rational as opposed to an empirical basis.

This work was generously supported by a grant from the Medical Research Council. We would like to thank M. Alexiou for critical comments on the manuscript.

\section{References}

Ardawi MSM and Newsholme EA (1982) Maximum activities of some enzymes of glycolysis, the tricarboxylic acid cycle and ketone-body and glutamine utilization pathways in lymphocytes of the rat Biochemical Journal 208 743-748

Barbehenn EK, Wales RG and Lowry OH (1974) The explanation for the blockage of glycolysis in early mouse embryos Proceedings of the National Academy of Sciences USA 71 1056-1060

Barbehenn EK, Wales RG and Lowry OH (1978) Measurement of metabolites in single preimplantation embryos: a new means to study metabolic control in early embryos Journal of Embryology and Experimental Morphology 43 29-46

Bergmeyer HU (1983) Methods of Enzymatic Analysis, Vol. II. Samples, Reagents, Assessment of Results (3rd edn) Weinheim, Verlag Chemie

Biggers JD and Stern S (1973) Metabolism of the preimplantation mammalian embryo Advances in Reproductive Physiology 6 1-60

Blomstrand E, Challiss RAJ, Cooney CJ and Newsholme EA (1983) Maximal activities of hexokinase, 6-phosphofructokinase, oxoglutarate dehydrogenase, and carnitine palmitoyltransferase in rat and avian muscles Bioscience Reports 3 1149-1153

Blomstrand E, Ekblom B and Newsholme EA (1986) Maximum activities of key glycolytic and oxidative enzymes in human muscle from differently trained individuals Joumal of Physiology 381 111-118

Board M, Humm S and Newsholme EA (1990) Maximum activities of key enzymes of glycolysis, glutaminolysis, pentose phosphate pathway and tricarboxylic acid cycle in normal, neoplastic and suppressed cells Biochemical Joumal 265 503-509

Braude P, Bolton V and Moore S (1988) Human gene expression first occurs between the four- and eight-cell stages of preimplantation development Nature 332 459-461

Brinster RL (1965) Lactate dehydrogenase activity in the preimplanted mouse embryo Biochimica et Biophysica Acta 100 439-441 
Brinster RL (1966) Glucose 6-phosphate dehydrogenase activity in the preimplantation mouse embryo Biochemical Journal 101 161-163

Brinster RL (1968a) Hexokinase activity in the preimplantation mouse embryo Enzymologia 34 304-308

Brinster RL (1968b) Lactate dehydrogenase activity in the oocytes of mammals Journal of Reproduction and Fertility 17 139-146

Brinster RL (1971) Phosphofructokinase activity in the preimplantation mouse embryo Wilhelm Roux Archives 166 300-302

Brison DR and Leese HJ (1991) Energy metabolism in late preimplantation rat embryos Journal of Reproduction and Fertility 93 245-251

Budohoski L, Challis RAJ and Newsholme EA (1982) Effects of starvation on the maximal activities of some glycolytic and citric acid-cycle enzymes and glutaminase in mucosa of the small intestine of the rat Biochemical Joumal 206 169-172

Chatot C, Ziomek CA, Bavister BD, Lewis JL and Torres I (1989) An improved culture medium supports development of random-bred 1-cell mouse embryos in vitro Journal of Reproduction and Fertility 86 679-688

Chi MM-Y, Manchester JK, Yang VC, Curato AD, Strickler RC and Lowry OH (1988) Contrast in levels of metabolic enzymes in human and mouse ova Biology of Reproduction 39 295-307

Conaghan J, Hardy K, Handyside AH, Winston RML and Leese HJ (1993) Selection criteria for human embryo transfer: a comparison of pyruvate uptake and morphology Journal of Assisted Reproduction and Genetics 10 $21-30$

Cooney GJ, Taegtmeyer H and Newsholme EA (1981) Tricarboxylic acid cycle flux and enzyme activities in the isolated working rat heart Biochemical journal $200701-703$

Crabtree B and Newsholme EA (1972) The activities of phosphorylase hexokinase, phosphofructokinase, lactate dehydrogenase and the glycerol 3-phosphate dehydrogenases in muscles from vertebrates and invertebrates Biochemical Joumal 126 49-58

Epstein CJ, Wegienka EA and Smith CW (1969) Biochemical development of preimplantation mouse embryos: in vivo activities of fructose 1,6-diphosphate aldolase, glucose 6-phosphate dehydrogenase, malate dehydrogenase and lactate dehydrogenase Biochemical Genetics 3 271-281

Fridhandler L (1961) Pathways of glucose metabolism in fertilized rabbit ova at various preimplantation stages Experimental Cell Research 22 303-316

Gardner DK and Leese HJ (1986) Non-invasive measurement of nutrient uptake by single cultured preimplantation mouse embryos Human Reproduction 1 $25-27$

Gardner DK and Leese HJ (1988) The role of glucose and pyruvate transport in regulating nutrient utilization by preimplantation mouse embryos Development 104 423-429

Gott AL, Hardy K, Winston RML and Leese HJ (1990) Non-invasive measurement of pyruvate and glucose uptake and lactate production by single mouse preimplantation embryos Human Reproduction 5 104-108

Hardy K (1992) Development of human blastocysts in vitro. In Preimplantation Embryo Development Serono Symposia pp 184-199 Ed. BD Bavister. SpringerVerlag, New York

Hardy K, Hooper MAK, Handyside AH, Rutherford AJ, Winston RML and Leese HJ (1989) Non-invasive measurement of glucose and pyruvate uptake by individual human oocytes and preimplantation embryos Human Reproduction 4 188-191

Hillier SG, Dawson KJ, Afhan M, Margara RA, Ryder TA, Wickings EJ and Winston RML (1984) Embryo culture: quality control in in vitro fertilisation. In Proceedings of the Twelfth Study Group of the Royal College of Obstetricians and Gynaecologists pp 125-140 Eds W Thompson, DN Joyce and JR Newton. Royal College of Obstetricians and Gynaecologists, London

Hillier SG, Afhan AMM, Margara RA and Winston RML (1985) Superovulation strategy before in vitro fertilisation Clinical Obstetrics and Gynaecology 12 $687-723$

Hooper MAK and Leese HJ (1989) Activity of hexokinase in mouse oocytes and preimplantation embryos Biochemical Society Transactions 629 546-547

Hsieh B, Chi MM-Y, Knor J and Lowry OH (1979) Enzymes of glycogen metabolism and related metabolites in preimplantation mouse embryos Developmental Biology 72 342-349

Lawitts JA and Biggers JD (1992) Joint effects of sodium chloride, glutamine, and glucose in mouse preimplantation embryo culture media Molecular Reproduction and Development 31 189-194

Leese HJ (1987) Non-invasive methods for assessing embryos Human Reproduction 2 435-438
Leese HJ (1991) Metabolism of the preimplantation mammalian embryo. In Oxford Reviews of Reproductive Biology 13 35-72

Leese $\mathrm{HJ}$ and Barton AM (1984) Pyruvate and glucose uptake by mouse ova and preimplantation embryos Joumal of Reproduction and Fertility 72 9-13

Leese HJ, Biggers JD, Mroz EA and Lechene C (1984) Nucleotides in a single mammalian ovum or preimplantation embryo Analytical Biochemistry 140 443-448

Lowry OH and Passoneau JV (1964) The relationships between substrates and enzymes of glycolysis in brain Joumal of Biological Chemistry 239 31-41

Lowry OH and Passoneau JV (1972) A Flexible System of Enzymatic Analysis. Academic Press, New York

Lowry CV, Kimmey JS, Felder S, Chi MM-Y, Kiaser K, Passoneau PN, Kirk KA and Lowry $\mathrm{OH}$ (1978) Enzyme patterns in single human muscle fibers Journal of Biological Chemistry 253 8269-8277

Lowry OH, Berger SJ, Carter JG, Chi MM-Y, Manchester JK, Knor J and Pusateri ME (1983) Diversity of metabolic patterns in human brain tumors: enzymes of energy metabolism and related metabolites and cofactors Journal of Neurochemistry 41 994-1010

Mroz EA and Lechene $C$ (1980) An NADH-coupled assay for femtogram or nanogram quantities of chymotrypsin Analytical Biochemistry 128 181-185

Newsholme EA and Crabtree B (1986) Maximum catalytic activity of some key enzymes in provision of physiologically useful information about metabolic fluxes Joumal of Experimental Zoology 239 159-167

Newsholme EA and Leech AR (1981) Biochemistry for the Medical Sciences. John Wiley and Sons Ltd, London.

Newsholme EA and Start C (1973) Regulation in Metabolism. John Wiley and Sons Ltd, London

Newsholme EA, Crabtree B and Zammit VA (1980) Use of enzyme activities as indices of maximum rates of fuel utilization Ciba Foundation Symposia $\mathbf{7 3}$ $245-258$

O'Fallon JV and Wright R Jr (1986) Quantitative determination of the pentose phosphate pathway in preimplantation mouse embryos Biology of Reproduction 34 58-64

Quinn P, Barros C and Whittingham DG (1982) Preservation of hamster oocytes to assay the fertilizing capacity of human semen Journal of Reproduction and Fertility 66 161-168

Shonk CE and Boxer GE (1964) Enzyme patterns in human tissues. I. Methods for the determination of glycolytic enzymes Cancer Research 24 709-721

Shonk CE, Koven BJ, Majma H and Boxer GE (1964) Enzyme patterns in human tissues. II. Glycolytic enzyme patterns in non-malignant human tissues Cancer Research 24 722-731

Randle PJ, England PJ and Denton RM (1970) Control of the tricarboxylate cycle and its interactions with glycolysis during acetate utilization in rat heart Biochemical Journal $117677-695$

Read G, Crabtree B and Smith G (1977) The activities of 2-oxoglutarate dehydrogenase and pyruvate dehydrogenase in heart and mammary glands from ruminants and non-ruminants Biochemical Joumal 164 349-355

Rutherford AJ, Subak-Sharpe R, Dawson K, Margara RA, Franks S and Winston RML (1988) Dramatic improvement in IVF success following treatment with LHRH agonist British Medical Journal 296 1765-1768

Tesarik J (1988) Developmental control of human preimplantation embryos: a comparative approach Journal of in Vitro Fertilization and Embryo Transfer 5 347-362

Tsutsumi O, Yano T, Satoh K, Mizuno M and Kato T (1990) Studies of hexokinase activity in human and mouse oocytes American Journal of Obstetrics and Gynecology 162 1301-1304

Turner K, Goldstein DJ and Rogers AW (1992) Variation in the dry mass of mouse embryos throughout the preimplantation period Human Reproduction $7112-116$

Wales RG (1975) Maturation of the mammalian embryo: biochemical aspects Biology of Reproduction 12 66-81

Wales RG, Whittingham DG, Hardy K and Craft IL (1987) Metabolism of glucose by human embryos Journal of Reproduction and Fertility 79 289-297

West JD, Leask R and Green JF (1986) Quantification from oocyte-coded to embryo-coded glucose phosphate isomerase in mouse embryos Joumal of Embryology and Experimental Morphology 97 225-237

West JD, Flockhart JH, Angell RR, Hillier SG, Thatcher SS, Glasier AF, Rodger MW and Baird DT (1989) Glucose phosphate isomerase activity in mouse and human eggs and pre-embryos Human Reproduction 4 82-85 